Prepared for the U.S. Department of Energy under Contract DE-AC05-76RL01830

\title{
Source/Sink Matching for U.S. Ethanol Plants and Candidate Deep Geologic Carbon Dioxide Storage Formations
}

\section{RT Dahowski}

JJ Dooley

September 2008

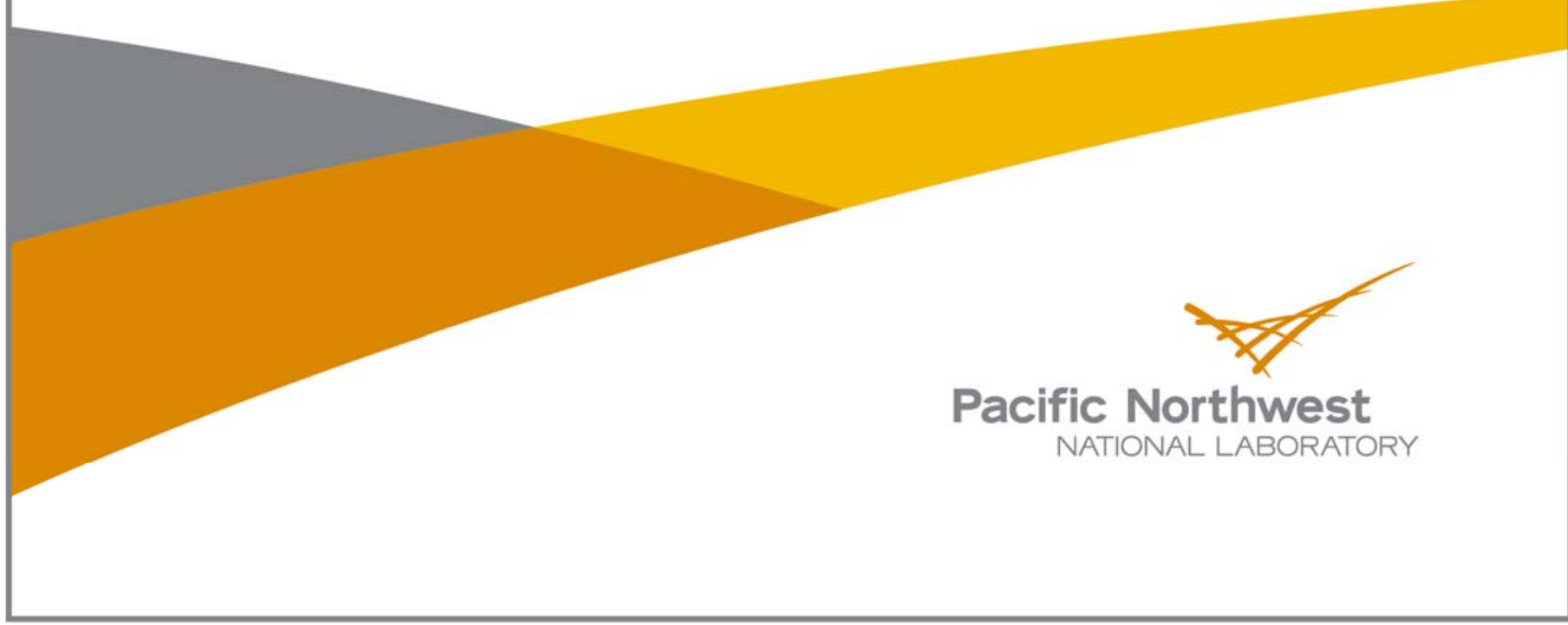




\title{
DISCLAIMER
}

This report was prepared as an account of work sponsored by an agency of the United States Government. Neither the United States Government nor any agency thereof, nor Battelle Memorial Institute, nor any of their employees, makes any warranty, express or implied, or assumes any legal liability or responsibility for the accuracy, completeness, or usefulness of any information, apparatus, product, or process disclosed, or represents that its use would not infringe privately owned rights. Reference herein to any specific commercial product, process, or service by trade name, trademark, manufacturer, or otherwise does not necessarily constitute or imply its endorsement, recommendation, or favoring by the United States Government or any agency thereof, or Battelle Memorial Institute. The views and opinions of authors expressed herein do not necessarily state or reflect those of the United States Government or any agency thereof.

\author{
PACIFIC NORTHWEST NATIONAL LABORATORY \\ operated by \\ BATTELLE \\ for the \\ UNITED STATES DEPARTMENT OF ENERGY \\ under Contract DE-AC05-76RL01830
}

Printed in the United States of America
Available to DOE and DOE contractors from the Office of Scientific and Technical Information,
P.O. Box 62, Oak Ridge, TN 37831-0062;
ph: (865) 576-8401
fax: $(865)$ 576-5728
email: reports@adonis.osti.gov

\begin{abstract}
Available to the public from the National Technical Information Service, U.S. Department of Commerce, 5285 Port Royal Rd., Springfield, VA 22161 ph: (800) 553-6847 fax: $(703) 605-6900$ email: orders@ntis.fedworld.gov online ordering: http://www.ntis.gov/ordering.htm
\end{abstract}

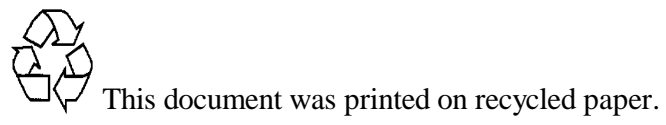


PNNL-17831

\section{Source/Sink Matching for U.S. Ethanol Plants and Candidate Deep Geologic Carbon Dioxide Storage Formations}

RT Dahowski

JJ Dooley

September 2008

Prepared for

the U.S. Department of Energy

under Contract DE-AC05-76RL01830

Pacific Northwest National Laboratory

Richland, Washington 99352 


\begin{abstract}
This report presents data on the 140 existing and 74 planned ethanol production facilities and their proximity to candidate deep geologic storage formations. Half of the existing ethanol plants and $64 \%$ of the planned units sit directly atop a candidate geologic storage reservoir, while $70 \%$ of the existing and $97 \%$ of the planned units are within 100 miles of at least one candidate deep geologic storage reservoir. As a percent of the total $\mathrm{CO}_{2}$ emissions from these facilities, $92 \%$ of the emissions from exiting units and $97 \%$ of the emissions from planned units are generated within 100 miles of at least one potential $\mathrm{CO}_{2}$ storage reservoir.
\end{abstract}

KEY WORDS: ethanol production, carbon dioxide capture and storage; climate change, United States. 
Figure 1 shows current and announced ethanol production facilities in the United States as well as candidate deep geologic $\mathrm{CO}_{2}$ storage reservoirs. ${ }^{1}$ As can be seen from Figure 1, while many ethanol facilities sit directly atop a potential storage formation, a significant percentage do not. This brief paper will examine the proximity of U.S. ethanol production facilities to candidate storage reservoirs, as well as the implications of this analysis for the potential deployment of carbon dioxide capture and storage (CCS) technologies within the U.S. ethanol industry.

\section{Figure 1: Candidate Deep Geologic $\mathrm{CO}_{2}$ Storage Reservoirs and Current and Planned Ethanol Production Facilities}

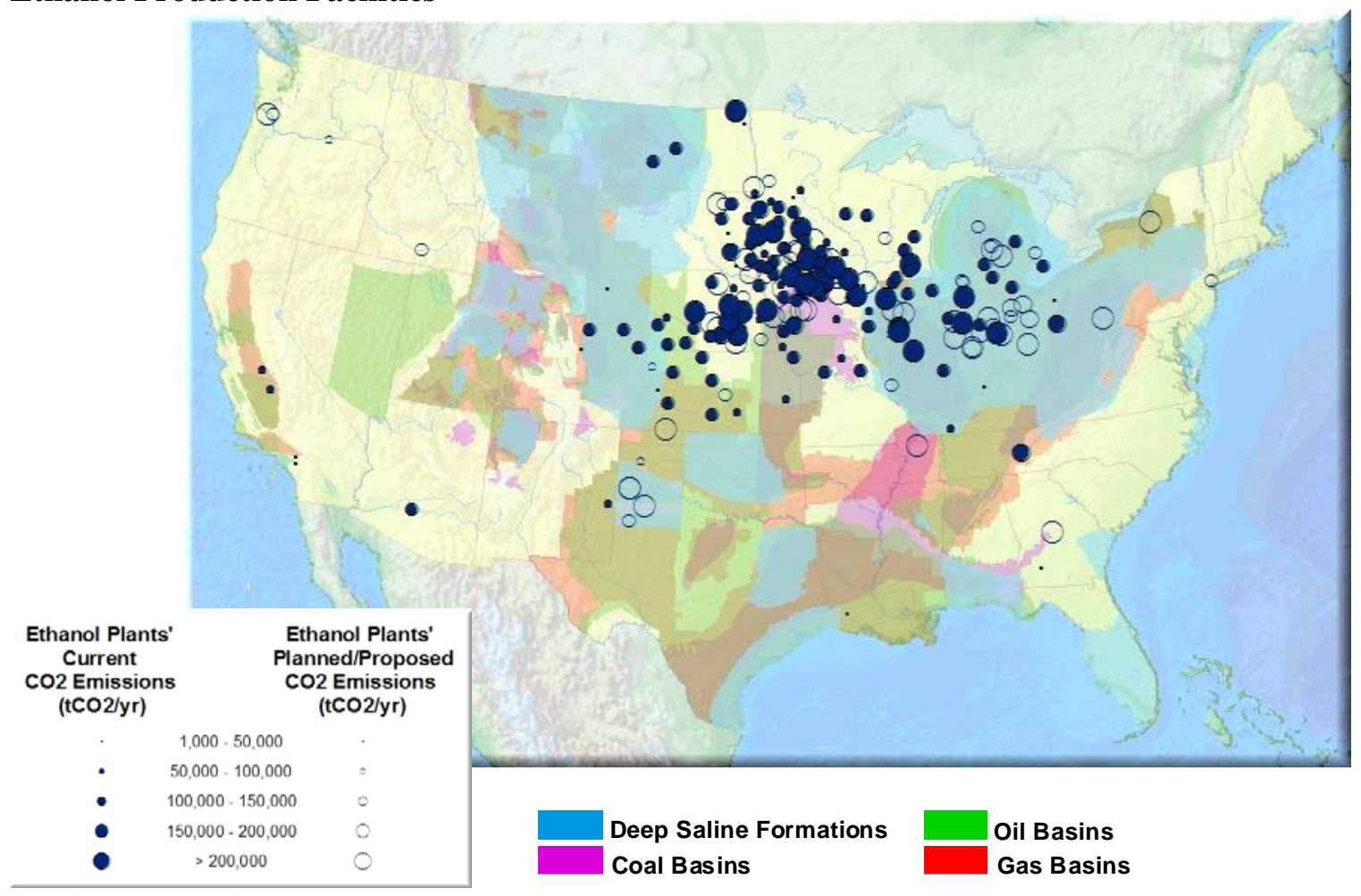

${ }^{1}$ A description of the United States' massive and geographically dispersed theoretical geologic $\mathrm{CO}_{2}$ storage capacity can be found in RT Dahowski, JJ Dooley, CL Davidson, S Bachu, and N Gupta. 2005. Building the Cost Curves for $\mathrm{CO}_{2}$ Storage: North America. Technical Report 2005/3. IEA Greenhouse Gas R\&D Programme. 


\section{Overview of U.S. Ethanol Plants}

Table 1 presents an overview of the existing and planned U.S. ethanol production infrastructure using the most recently available data.

Table 1: Overview of Existing and Planned Ethanol Production Facilities

$\begin{array}{lccc} & \text { Existing Facilities } & \begin{array}{c}\text { Planned } \\ \text { Facilities }\end{array} & \text { Total } \\ \begin{array}{l}\text { Number of } \\ \text { Facilities }\end{array} & 140 & 74 & 214 \\ \begin{array}{l}\text { Total Emissions, } \\ \mathrm{MtCO}_{2} / \mathrm{yr}\end{array} & 19.3 & 15.1 & 34.4\end{array}$

Ethanol plants are seen as potential early adopters of CCS systems as the cost of capturing $\mathrm{CO}_{2}$ from these facilities is believed to be quite low. The fermentation process involved in producing ethanol results in a very pure stream of $\mathrm{CO}_{2}$ that is typically vented to the atmosphere. If there were a policy in place that created a disincentive for venting $\mathrm{CO}_{2}$ to the atmosphere, the $\mathrm{CO}_{2}$ stream from these ethanol plants would only need to be dehydrated (to prevent corrosion in $\mathrm{CO}_{2}$ pipelines) and compressed to typical pipeline pressures. The cost of capture (including dehydration and compression) from these facilities could be in the range of $\$ 6-12 /$ tonCO$_{2}$, which is far lower than the potential costs to capture and prepare pipeline-ready $\mathrm{CO}_{2}$ from even the most modern coal fired power plants. ${ }^{2}$ For this reason, industrial facilities such as ethanol plants that produce high purity $\mathrm{CO}_{2}$ streams are often seen as early opportunities for CCS deployment.

\section{Source Sink Matching Transporting $\mathrm{CO}_{2}$ from Ethanol Facilities}

While the cost of capturing $\mathrm{CO}_{2}$ from ethanol plants is considered to be quite low, the captured $\mathrm{CO}_{2}$ still needs to be delivered to a suitable deep geologic storage reservoir, injected into that reservoir, and monitored for safety and efficacy. The cost of transport (which for the U.S. and many other parts of the world will almost surely be by dedicated $\mathrm{CO}_{2}$ pipelines) ${ }^{3}$ is likely to be another significant cost element, particularly on a per-ton basis given the relatively low-volume $\mathrm{CO}_{2}$ streams produced by ethanol facilities. ${ }^{4}$

\footnotetext{
2 JJ Dooley, CL Davidson, RT Dahowski, MA Wise, N Gupta, SH Kim, EL Malone, "Carbon Dioxide Capture and Geologic Storage: A Key Component of a Global Energy Technology Strategy to Address Climate Change." Joint Global Change Research Institute, Battelle Pacific Northwest Division. May 2006. PNWD-3602. College Park, MD.

${ }^{3}$ IPCC Special Report on Carbon Dioxide Capture and Storage. 2005. Prepared by Working Group III of the Intergovernmental Panel on Climate Change [B Metz, O Davidson, H de Conick, M Loos, and L Meyer] Cambridge University Press, Cambridge, United Kingdom, 442 pp.

${ }^{4}$ Joel Sminchak, Robert Dahowski, James Dooley, Casie Davidson, and Neeraj Gupta. Developing a Better Understanding of the Cost of $\mathrm{CO}_{2}$ Transport and Storage: Moving Beyond a Fixed Storage Cost Assumption. Presented at the Sixth Annual Conference on Carbon Capture and Sequestration. Pittsburgh. May 9, 2007. Joint Global Change Research Institute. Battelle. PNWD-SA-7806.
} 
Source Sink Matching for Existing Ethanol Production Facilities

Table 2 presents summary information on the existing ethanol facilities and their proximity to candidate deep geologic $\mathrm{CO}_{2}$ storage formations. As shown in Table 2, 50\% of the existing ethanol plants (which cumulatively account for $46 \%$ of the $\mathrm{CO}_{2}$ produced from all existing ethanol plants) sit directly atop a candidate deep geologic $\mathrm{CO}_{2}$ storage formation. If the search radius is expanded to 50 miles, 85 existing ethanol plants (61\%) could reach a candidate $\mathrm{CO}_{2}$ storage reservoir. If the search radius is extended to 100 miles, 110 existing facilities accounting for $92 \%$ of the cumulative $\mathrm{CO}_{2}$ from these existing ethanol plants could likely reach at least one deep geologic $\mathrm{CO}_{2}$ storage formation.

Table 2: Existing Ethanol Facilities and their Distance to Candidate Deep Geologic $\mathrm{CO}_{2}$ Storage Reservoirs

$\begin{array}{lcccc} & \begin{array}{c}\text { Number of } \\ \text { Facilities }\end{array} & \begin{array}{c}\text { \% of } \\ \text { Facilities }\end{array} & \begin{array}{c}\text { Total } \\ \text { Emissions, } \\ \mathbf{M t C O}_{2} / \mathbf{y r}\end{array} & \begin{array}{c}\text { \% Of } \\ \text { Emissions }\end{array} \\ \mathbf{0} \text { miles } & 70 & 50 \% & 19.3 & 46 \% \\ \mathbf{5 0} \text { miles } & 85 & 61 \% & 9.0 & 76 \% \\ \mathbf{1 0 0} \text { miles } & 110 & 79 \% & 14.8 & 92 \% \\ \text { Total } & 140 & 100 \% & 19.3 & 100 \%\end{array}$

Source Sink Matching for Planned Ethanol Production Facilities

Table 3 presents summary information on the planned ethanol facilities and their proximity to candidate deep geologic $\mathrm{CO}_{2}$ storage formations. As can be seen from Table 3, 64\% of the planned plants (62\% of the planned units $\mathrm{CO}_{2}$ emissions), appear to sit atop a candidate deep geologic $\mathrm{CO}_{2}$ storage formation. If pipeline lengths of up to 50 miles are considered, then slightly more than $80 \%$ of the facilities and a similar percentage of their $\mathrm{CO}_{2}$ emissions should be able to reach a candidate $\mathrm{CO}_{2}$ storage reservoir. If the search radius is extended to 100 miles, virtually all of the facilities and their associated emissions ( $97 \%$ by both measures) should be able to reach a candidate deep geologic $\mathrm{CO}_{2}$ storage reservoir.

Table 3: Existing Ethanol Facilities and their Distance to Candidate Deep Geologic $\mathrm{CO}_{2}$ Storage Reservoirs

$\begin{array}{lcccc} & \begin{array}{c}\text { Number of } \\ \text { Facilities }\end{array} & \begin{array}{c}\text { \% of } \\ \text { Facilities }\end{array} & \begin{array}{c}\text { Total } \\ \text { Emissions, } \\ \mathbf{M t C O}_{2} / \mathbf{y r}\end{array} & \begin{array}{c}\text { \% Of } \\ \text { Emissions }\end{array} \\ \mathbf{0} \text { miles } & 47 & 64 \% & 9.4 & 62 \% \\ \mathbf{5 0} \text { miles } & 60 & 81 \% & 12.5 & 83 \% \\ \mathbf{1 0 0} \text { miles } & 72 & 97 \% & 14.7 & 97 \% \\ \text { Total } & 74 & 100 \% & 15.1 & 100 \%\end{array}$

The following figures illustrate the findings for both the existing and planned ethanol facilities. Figure 2 shows the distance from each current and planned ethanol production facility to the nearest candidate $\mathrm{CO}_{2}$ storage formation. Figure 3 shows the cumulative estimated $\mathrm{CO}_{2}$ emissions from these same sets (and order) of plants. Figure 4 shows a preliminary estimate of 
cumulative $\mathrm{CO}_{2}$ pipeline requirements, assuming individual pipelines from each plant to nearest storage reservoir, with a $17 \%$ routing factor and 10 mile adder to locate a suitable injection location .

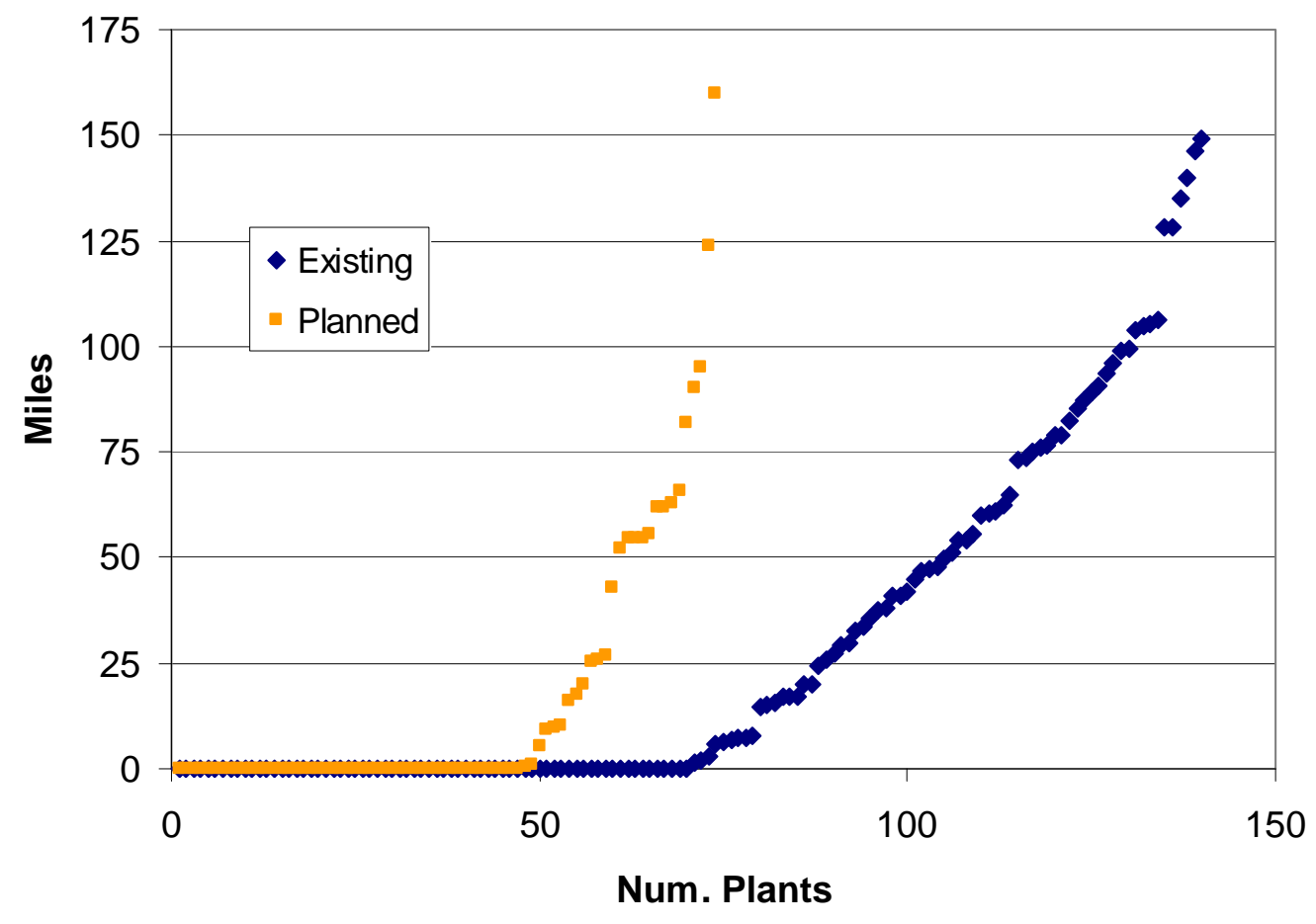

Figure 2: Distance in Miles to Nearest Candidate Deep Geologic $\mathrm{CO}_{2}$ Storage Formation for Both Existing and Current Ethanol Plants 


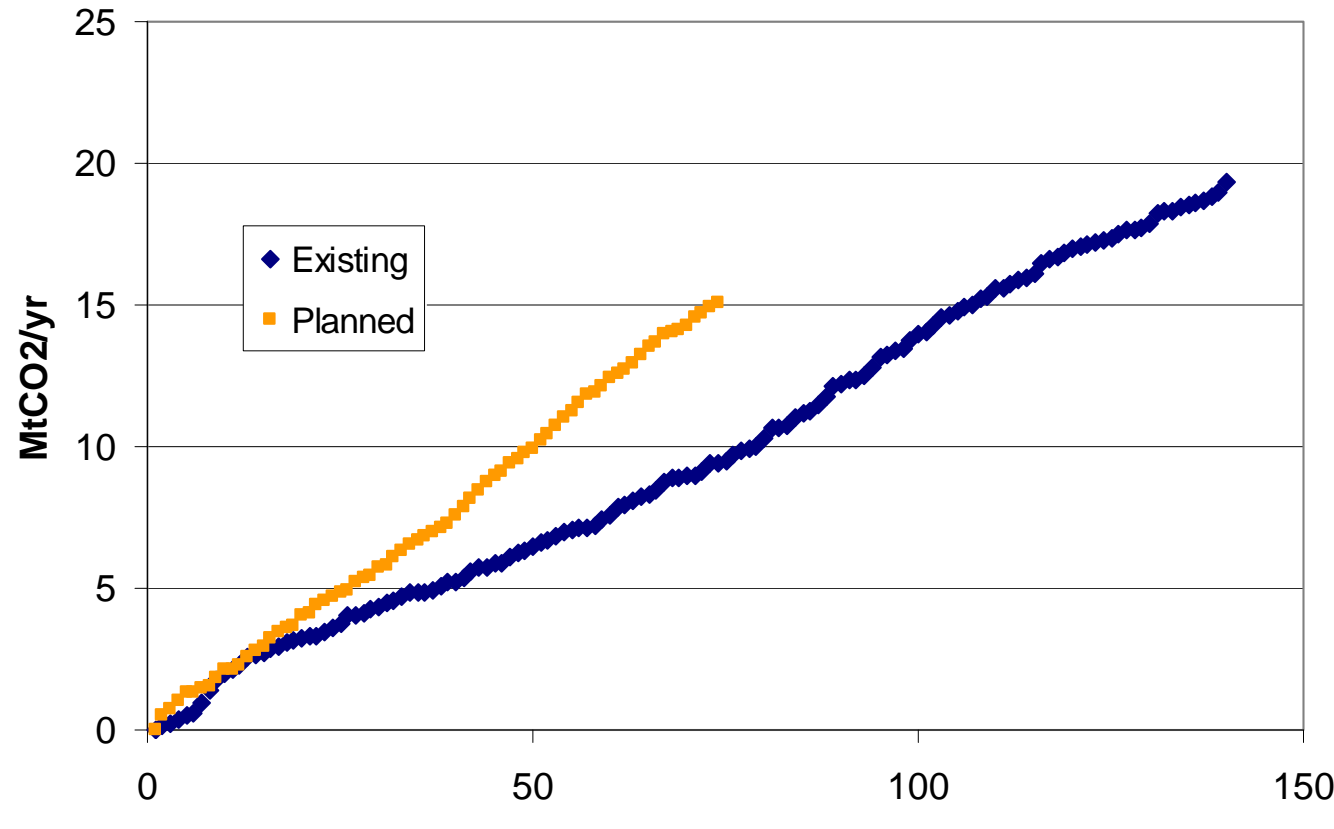

Num. Plants

Figure 3: Cumulative Estimated $\mathrm{CO}_{2}$ Emissions for the Set of Existing and Planned Ethanol Production Facilities Shown in Figure 2.

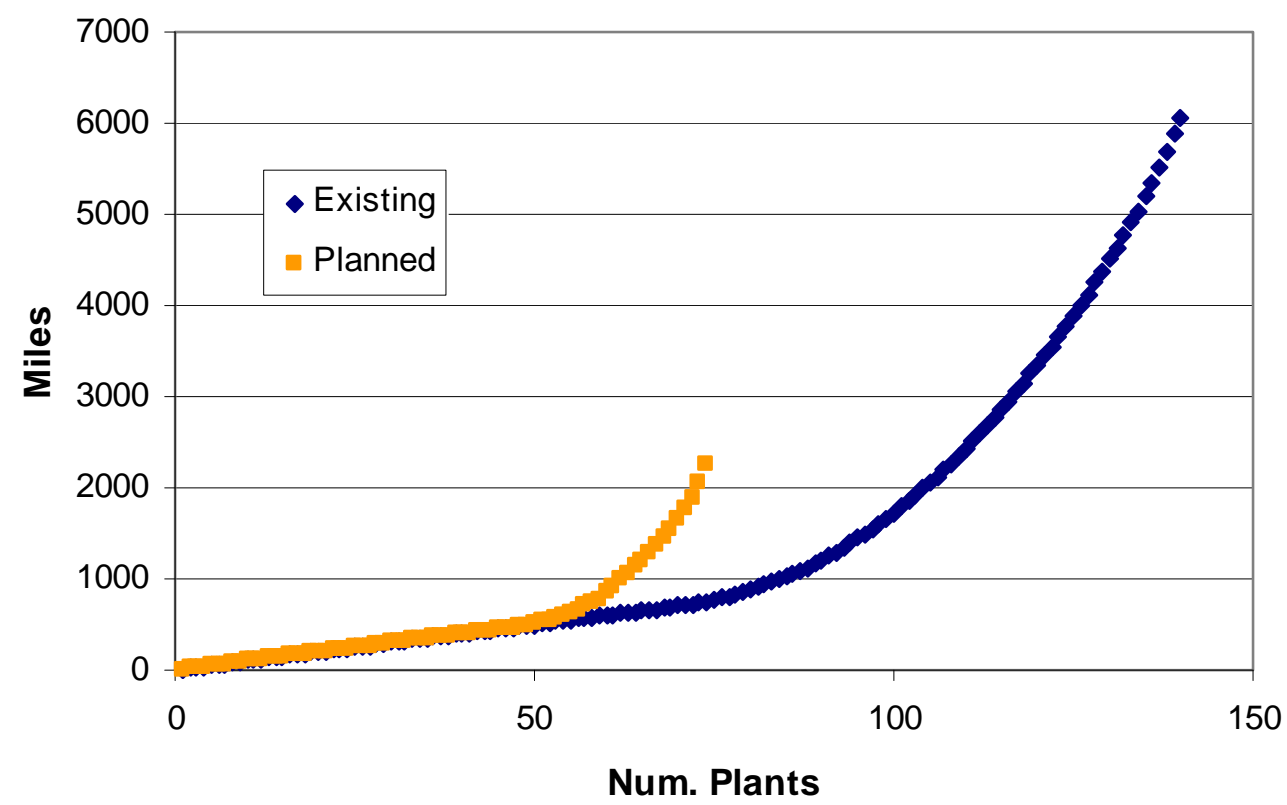

Figure 4: Estimated Cumulative $\mathrm{CO}_{2}$ Pipeline Infrastructure for the Set of Existing and Planned Ethanol Production Facilities Shown in Figure 2. 